\title{
Detection of medroxyprogesterone acetate residues in animal muscle tissues by using enzyme-linked immunosorbent assay and liquid chromatography tandem mass spectrometry*
}

\author{
ChL. Xu' ${ }^{1}$, Ch. Pen, K. Hao, Z. Jin, X. Chu and L.Wang \\ School of Food Science and Technology, Southern Yangtaze University \\ 214036, WuXi, JiangSu Province, China
}

(Received 8 August 2005; accepted 17 October 2005)

\begin{abstract}
Medroxyprogesterone acetate (MPA) has a relative molecular mass of only 344.5 and no immunoreactivity. Methods using carbodiimides and mixed anhydrides were adapted to couple MPA with bovine serum albumin, a carrier protein. The coupling rates of conjugate using the above methods were estimated to be 14 and 20 by ultraviolet spectrophotometry. The coupling was successful according to SDS-PAGE. New Zealand White rabbits were immunized with the conjugate obtained with a coupling rate of 14 , and blood was collected after five periods of immunities. Indirect ELISA showed the titer of antiserum to be $2.6 \times 10^{5}$. Based on the purified antibody, a competitive indirect ELISA was developed. It provided a limit of detection of $0.096 \mathrm{ng} / \mathrm{mL}$, recoveries (edible tissues) between 72 and $91 \%$ and a working range of $0.1-8.1 \mathrm{ng} / \mathrm{mL}$. Preliminary evaluation of assay performance in terms of specificity, sensitivity, precision, and accuracy showed that this ELISA can be applied to practical detection of MPA in tissues. Moreover, it was compared with high performance liquid chromatography tandem mass spectrometry. The ion pair for quantification of MPA was 345.2/123.1, and linear equation of MPA was $\mathrm{Y}=6.68 \times 10^{3} \mathrm{X}+6.63 \times 10^{2}$. The two analytical methods can be applied to monitor MPA and other anabolic steroid residues in foods.
\end{abstract}

KEY WORDS: coupling, medroxyprogesterone acetate, animal tissues, enzyme-linked immunosorbent assay (ELISA), liquid chromatography tandem mass spectrometry

\footnotetext{
* Supported by the National Natural Science Foundation of China (20475022) and the Ministry of Science and Technology of China, Research Project No. 2001BA804A11

${ }^{1}$ Corresponding author: e-mail: xcl@sytu.edu.cn
} 


\section{INTRODUCTION}

Medroxyprogesterone acetate (MPA) is a synthetic gestagen. It is often used in human medicine and is widely applied in the treatment of hormone-dependent tumors. As a veterinary drug, MPA is considered to be a hormone that can highly speed up fattening (Bernard, 1971). In order to test MPA residue levels by ELISA, the first thing is to prepare an anti-MPA antibody characterized by good specificity and a high biological titer. The relative molecular mass of MPA is only 344.5 and it has no immunogenicity, so it cannot stimulate animals to produce a corresponding antibody directly, though it has immune reactivity and can form a hapten-antibody complex with its specific antibody. Moreover, without coupling with a carrier protein, low-molecular substances are poorly absorbed by solid-phase carriers; through the protein, the hapten can be invested to the solid-phase carrier (Choi et al., 2000).

The methods currently used for determining anabolic steroid residues in animal muscle tissues are high performance liquid chromatography and tandem mass spectrometry and gas chromatography-mass spectrometry (Daeseleire et al., 1991; Draisci et al., 1998; Philippe et al., 1999; Choi et al., 2000; Stolker et al., 2002; Rambaud et al., 2005), but sample preparation was trivial (Rapp et al., 1989; Yu et al., 2005).

The objective of the present study was to develop a method of determining medroxyprogesterone acetate residues in pork tissues by enzyme-linked immunosorbent assay (ELISA), and to compare it with high performance liquid chromatography and tandem mass spectrometry. To our knowledge, the present paper describes for the first time an inexpensive, simple, rapid and reliable ELISA for pork tissue MPA. The method is potentially applicable for other gestagen or gestagen metabolite determinations.

In the development of ELISA, the key problem is the synthesis of the MPA complete antigen (Lewis et al., 1992). In our study, MPA was coupled with bovine serum albumin (BSA) in two different ways: using the carbodiimide (method A) and mixed anhydride (method B) procedures. The coupling rates of the two compounds were then tested separately. Experiments using SDS-PAGE and animal antibodies showed that the synthesis of MPA complete antigen is quite successful, which lays a good foundation for the development of an MPA testing kit using ELISA.

\section{MATERIAL AND METHODS}

\section{Equipment and reagents}

Electronic Balance AB104-N (Shanghai Metller Toledo Group); ElectroThermostatic Blast Oven (Shanghai Yuejin Medical Instruments Factory); 
PHS-3TC acidimeter (Shanghai Tianda Apparatus Co., Ltd.); Auto DoubleLayer Quartz Distillatory (Ronghua Apparatus Manufacturing Co., Ltd., Jintan, Jiangsu); U-3000 UV scanner (Shimadzu, Japan); 722-style UV-Vis-NIR Spectrophotometer (Shanghai Analytical Instrument Overall Factory); BioRad mini gelatin cataphoresis apparatus (American Bio-Rad company); FTS EI585-Q freeze dryer (American Stone Ridgg); Multiscan MK3 Luminometer, Transrferpette, tips, and $8 \times 12$ Microlon ELISA Plates were obtained from Thermo Labsystems.

An Agilent 1100 series LC system (Delaware, USA) including G1313A quaternary pump, G1313A autosampler, G1316A column oven were used for all analyses. All analytes were separated using a $150 \times 2.1 \mathrm{~mm}$ SUPELCO Discovery ${ }^{\circledR} \mathrm{C}_{18}$ column (MA, USA) with a $5 \mu \mathrm{m}$ particle size. A binary gradient consisting of acetonitrile (A) and purified water (B) at a flow rate of $0.3 \mathrm{~mL} /$ min was used. An injection volume of $10 \mu \mathrm{L}$ was used for all analyses (Fluid Management System Inc., USA). The gradient was as follows: for androgens and progestogens the linear gradient protocol was $50 \%$ A to $100 \%$ A within 15.0 min. Mass spectrometry was performed using an API3000 Tandem Triple Quadruple mass spectrometer equipped with a TurboIonSpray ESI source (Palo Alto, CA, USA). The ion spray voltage was $3000 \mathrm{~V}$. High-purity nitrogen gas was used as the nebulizer, heater, curtain and collision gases. Heater gas was set at $7.5 \mathrm{~L} / \mathrm{min}$ and the TurboIonSpray probe temperature was maintained at $550^{\circ} \mathrm{C}$. The nebulizer and curtain gas flows were, respectively, 12 and $8 \mathrm{~L} / \mathrm{min}$, while the gas pressure in the collision cell was set at $3.4 \times 10^{-5}$ Torr. MRM was used for the multiple product ions of each analyte. Precursor/daughter ions were set to unit resolution and dwell time was $150 \mathrm{~ms}$.

MPA and ETS (epitestosterone) standard samples were purchased from Sigma; all the other steroids used were supplied by Riedel-Deaen. BSA and OVA (ovalbumin) (Sino-American Biotechnology Company, import in bulk); methanol, ethyl acetate, isopropanol, perchloric acid and sodium borate analytical or HPLC grade, were from Sigma. Water-soluble carbodiimide (Sigma); CoomassieBrilliantBlue G250(ShanghaiBoaoBiotechCo.,Ltd.); hydroxylamine $\mathrm{HCl}$ (Shanghai Chemical Agent Company, AR); succinic anhydride (Kunshan Niansha Auxiliary Agent Factory, CP); N,N-dimethylformamide (Wuxi Chinese Traditional and Western Medicine Group Co., Ltd., AR); triethylamine (Shanghai Chemical Agent Company, AR); tributylamine Shanghai Chemical Agent Company, CP); isobutyl chlorocarbonate (Shanghai Feixiang Chemical Factory, CP); 1-ethyl-3-(3-dimethylaminopropyl)-carbodiimide (EDCI); 1,4-dioxane; phosphate buffered saline (PBS) (Shanghai Chemical Reagent Station, AR). 


\section{MPA-BSA conjugate}

Method A. At oximation, MPA ( $85 \mathrm{mg}$, about $0.25 \mathrm{~mol}$ ) was dissolved in $20 \mathrm{~mL}$ of anhydrous ethanol and hydroxylammonium chloride $(21 \mathrm{mg})$ was dissolved in $10 \mathrm{~mL}$ of double-distilled water. Then the two solutions were blended and reacted in an ice-bath for $2.5 \mathrm{~h}$ during which about $7 \mathrm{~mL}$ of $\mathrm{NaOH}\left(0.05 \mathrm{~mol} \mathrm{~mL}^{-1}\right)$ was dripped in gradually. A white deposit appeared after acetate - buffer $(5 \mathrm{~mL})$ and chip ice (about $25 \mathrm{mg}$ ) were added. The solution was then stored for one day at $4^{\circ} \mathrm{C}$ (Wang, 1997).

The above solution was centrifuged and its supernatant fluid was discarded. The white sediment was dissolved in $20 \mathrm{~mL}$ of $\mathrm{N}, \mathrm{N}$-dimethylformamide and succinic anhydride $(50 \mathrm{mg})$ was added. After reaction at room temperature for $2 \mathrm{~h}$, triethylamine $(100 \mu \mathrm{L})$ was added and reacted again for an hour (Wang, 1997).

Coupling reaction of MPA and BSA. BSA (500 mg) and EDCI (100 mg) were dissolved in $10 \mathrm{~mL}$ of PBS $\left(0.01 \mathrm{~mol} \mathrm{~L}^{-1}, \mathrm{pH} 8.0\right)$, and then the above acylate was dripped gradually into the solution. EDCI $(50 \mathrm{mg})$ was added after an hour. The solution was then agitated in the dark, left overnight and dialysed against doubledistilled water for the next two days, with four changes of the water at intervals. Finally it was freeze-dried and preserved.

The method of MPA-OVA (ovalbumin) conjugation is the same as the above method A of MPA-BSA Conjugation.

Method B. The oximation and acylation of MPA are the same for the first several steps. After reaction with triethylamine for an hour, tributylamine (360 $\left.\mathrm{mm}^{3}\right)$ and isobutyl chlorocarbonate $\left(280 \mathrm{~mm}^{3}\right)$ were added and the reaction continued for an hour at $4^{\circ} \mathrm{C}$.

1, 4-Dioxane $(1 \mathrm{~mL})$ and BSA $(500 \mathrm{mg})$ were dissolved in $8 \mathrm{~mL}$ of distilled water, and then the above acylate was dripped gradually into the solution. The solution was reacted for $4 \mathrm{~h}$ at $4^{\circ} \mathrm{C}$. The end product was dialysed for $48 \mathrm{~h}$ at $4^{\circ} \mathrm{C}$. during which the dialysate was changed for four times, PBS solution for the first two changes, followed by distilled water. The dialysate was then freeze-dried and preserved.

\section{Identification of conjugate}

Identification of acylate. The entire reaction system, which changed from a clear solution to a white deposit, points to the process of oximation. TLC was applied after acylation with succinic anhydride.

According to the TLC result, the chromatographic band of acylated MPA clearly tailed that of original MPA which had not been acylated; the band of the former was situated higher on the chromatogram. The analysis shows the product of acylation. 
Electrophoresis of conjugate. The fact that the reaction system changed from clarity to a white deposit when the colourless acylated solution was added to the clear BSA solution identifies the production of MPA-BSA conjugate (Shen and Zhou, 1998).

\section{Coupling rate of MPA-BSA formation}

A spectrophotometric method was adopted to determine the coupling rate of MPA-BSA (Wang and Fan, 2000).

First, the content of the protein in the conjugate was tested by the method of Bradford (Wang, 1997) and Lowry (Wang and Fan, 2000). Though the conjugate comprised two kinds of molecular protein-hapten, the absolute content of conjugate was often expressed by the relative content of protein, due to the fact that the two contents were consistent. The Bradford method was, therefore, used to test the content.

BSA standard solution was prepared at the same concentration as the above resultant concentration. Different concentrations of MPA standard solutions (10 $\mu \mathrm{g} \mathrm{cm}^{-3}, 20 \mu \mathrm{g} \mathrm{cm}^{-3}, 25 \mu \mathrm{g} \mathrm{cm}^{-3}, 30 \mu \mathrm{g} \mathrm{cm}^{-3}$ ) were prepared and tested using a UV-3000 scanner. It showed that $247 \mathrm{~nm}$ was the maximum wavelength and the absorbance was tested under this wavelength.

The absorbance of BSA and MPA-BSA solutions was tested separately under the maximum wavelength of MPA. Afterwards, the coupling rate was calculated according to the Lambert-Beer law and the formulas referred to in Choi et al. (2000).

A series of MPA standard solutions $\left(10 \mu \mathrm{g} \mathrm{cm}^{-3}, 20 \mu \mathrm{g} \mathrm{cm}^{-3}, 25 \mu \mathrm{g} \mathrm{cm}^{-3}\right.$, $30 \mu \mathrm{g} \mathrm{cm}^{-3}$ ) was prepared and scanned by UV-scanner (Yang et al., 1998).

\section{Coupling rate of conjugate coupled by carbodiimides}

1. The protein concentration in the conjugate was tested by the method of Bradford and then the conjugate, according to the result, was diluted to two different concentrations: 26 and $65 \mu \mathrm{g} \mathrm{cm}{ }^{-3}$.

2. BSA standard solutions with the same concentrations as the above solution were prepared separately.

3. The above BSA solutions were tested by UV scanning and the maximum wavelength of BSA was determined as $278 \mathrm{~nm}$.

4. The absorbance of the four solutions mentioned above was determined at 247 $\mathrm{nm}$, the maximum wavelength of MPA. If water was used as the control, the absorbance of ethanol $(20 \%)$ at $\lambda=247 \mathrm{~nm}$ and $278 \mathrm{~nm}$ was 0.0944 and 0.0501 , respectively, which indicated that the error was acceptable if water was used as the solvent. Ethanol (20\%) could therefore be replaced by water. 


\section{Coupling rate of conjugate coupled by the mixed anhydride}

The coupling rate of conjugate coupled by the mixed anhydride method was tested as described above. But here, after determination of the concentration of protein in the conjugate, the concentrations of MPA-BSA and BSA were taken as 30 and $60 \mu \mathrm{g} \mathrm{cm}^{-3}$. They were next scanned by a UV scanner.

\section{Immunization of animals}

Three New Zealand female white rabbits were immunized with MPA-BSA conjugates synthesized using the carbodiimide method using the intradermalintravenous route (Marion, 1976; Draisci et al., 1998). Lyophilized MPA-BSA powder was dissolved in physiological saline to prepare a solution of $1 \mathrm{mg} \cdot \mathrm{mL}^{-1}$. The titers of antiserum were determined by ELISA. Antibodies were purified by ammonium sulphate precipitation followed by further purification using a Protein-A-Agarose affinity chromatography column. Antibody activity in fractions was verified by ELISA. Pooled fractions that showed maximum activity were stored at $-80^{\circ} \mathrm{C}$ in small portions $\left(0.5 \mathrm{~cm}^{-3}\right)$ (Shen and Zhou, 1998).

Antiserum titre determination procedures by ELISA were carried out as follows.

1. Microtitre plates (96 wells) were coated with a solution of MPA-OVA(Ovalbumin) $\left(0.2 \mathrm{~g} \mathrm{dm}^{-3}\right), 100 \mathrm{~mm}^{3}$ per well, and refrigerated overnight at $4^{\circ} \mathrm{C}$.

2. Microtitre plates were then blocked with the solution of OVA $\left(20 \mathrm{~g} \mathrm{dm}^{-3}\right), 200$ $\mathrm{mm}^{-3}$ each well, and kept for $2 \mathrm{~h}$ at $37^{\circ} \mathrm{C}$.

3. Four microtitre strips were prepared. The dilution of antibody was added in the first row as control, the second row was for negative serum $\left(\varphi_{\mathrm{r}}=1: 1000\right)$ and the next six rows were separately for positive serum $\left(\varphi_{\mathrm{r}}=1: 250,1: 1000\right.$, $\sim, 1: 256000), 100 \mathrm{~mm}^{3}$ per well, and the strips were kept for $1 \mathrm{~h}$ at room temperature.

4. Goat anti-rabbit IgG marked with horseradish peroxidase (HRP) was added, $100 \mathrm{~mm}^{3}$ per well, and kept for $1 \mathrm{~h}$ at room temperature.

5. TMB, a colour development reagent, was added and the plate was kept for 15 min at room temperature.

6. $\mathrm{H}_{2} \mathrm{SO}_{4}\left(2 \mathrm{~mol} \mathrm{dm}^{-3}\right)$ was added to stop the reaction and the absorbance at $\lambda=450 \mathrm{~nm}\left(\mathrm{OD}_{450}\right)$ was determined.

In each step above, the solution was washed with PBST solution three times and each time for $3 \mathrm{~min}$. A diagram, $\mathrm{OD}_{450}$ as ordinate, minus logarithm of antibody dilution factors as abscissa, was drawn. If $\mathrm{P} / \mathrm{N}$ (positive/negative) $\geq 2.1$, it was considered to be the titer of the antibody. 


\section{ic-ELISA procedure}

After blocking the plates with MPA-OVA, $50 \mu \mathrm{L}$ of sample or standard were dispensed into the appropriate well using a positive displacement pipette. Rabbit anti-MPA antibody $(50 \mu \mathrm{L})$ was added to each well and the plates were incubated for at least $2 \mathrm{~h}$. Each plate was washed prior to the addition of goat anti-rabbit HRP-IgG (100 $\mu \mathrm{L}$ per well). After another $2 \mathrm{~h}$ incubation, followed by washing, substrate solution $(100 \mu \mathrm{l}$ per well) was added. Colour development proceeded in the dark for approx. $20 \mathrm{~min}$. The assay was stopped by the addition of 100 $\mu \mathrm{L} 1.25 \mathrm{M} \mathrm{H} 2 \mathrm{SO} 4$ per well and the absorbance read at $450 \mathrm{~nm}$ on a Multiscan MK3 Luminometer. The zero standard was assayed in quadruplicate and all other standards and samples were assayed in duplicate. The four parameter sigmoidal standard curve was obtained on the basis of the above data.

\section{Cross reactivity (CR) assay}

There are several structural analogues of MPA: oestradiol, epitestosterone (ETS), nandrolone (17 $\beta$-NT), 17 $\alpha$-hydroxyprogesterone, 17 $\alpha$-methyl-testosterone (MTS), testosterone 17-propionate (PTS), cortisol, 17 $\beta$-oestradiol 3-benzoate (BES), progesterone (PG), dexamethasone, prednisolone, pregnenolone, deoxycorticosterone. These standard compounds were prepared with the same buffer as MPA at different concentrations, which acted as competitive substances to the antibody. All operations were carried out according to ic-ELISA process and $\mathrm{IC}_{50}$ was calculated based on the sigmoidal curve respectively. $\mathrm{CR}(\%)=\left(\mathrm{IC}_{50}\right.$ of MPA) $\left(\mathrm{IC}_{50}\right.$ of anabolic steroid analog) $\times 100 \%$.

\section{Sample pretreatment protocol}

Sample preparation. Healthy pigs were raised on feeds not containing any anabolic steroids at our school laboratory farm. When they were slaughtered, muscle tissues were sampled separately, and fat, skin and bones were discarded. Each pork tissue sample (100-200 g) was cut into pieces and chopped with a household appliance and then preserved by sealing in an airtight container and storing at $-20^{\circ} \mathrm{C}$.

Homogenization and enzymolysis. Pork tissue samples $(5.0 \pm 0.1 \mathrm{~g})$ were transferred to a centrifuge tube $(50 \mathrm{~mL})$ and acetic acid buffer $(10 \mathrm{~mL})$ was added. The solution was homogenized at 10000 r. p. m twice, each time for 20 s. An enzyme solution (100 $\mu \mathrm{L}$ ) was then added and the mixture was left at room temperature for 3 to $4 \mathrm{~h}$.

In preparation of spiked samples, homogenized standard solution was added into a centrifuge tube and enzyme solution was added after 10-15 min. Then it was hydrolysed in the same way as mentioned above. 
Extraction and purification. Methanol $(10 \mathrm{~mL})$ was added to the solution after enzymolysis. The solution was mixed by a vortex oscillator for $1 \mathrm{~min}$, extracted by immersing the tube into an ultrasonic bath for $5 \mathrm{~min}$ at room temperature and centrifuged at $2500 \times \mathrm{g}$ for $10 \mathrm{~min}$. The supernatant was transferred to another tube, mixed with tert-Butyl methyl ether $(15 \mathrm{~mL})$ by oscillator and then centrifuged at $2000 \times \mathrm{g}$ for $3 \mathrm{~min}$. The sublayer was reextracted with tert-Butyl methyl ether $(20 \mathrm{~mL}, 15 \mathrm{~mL})$ twice. The ether layers were collected, transferred to a rotary evaporation flask and the ether evaporated at $40^{\circ} \mathrm{C}$. The residue was dissolved in $0.5 \mathrm{~mL}$ methanol and $5 \mathrm{~mL}$ water were added.

The solution in the flask was loaded onto a $\mathrm{C}_{18}$ Solid-Phase extraction cartridge $(500 \mathrm{mg} / 3 \mathrm{~mL})$ which had previously been primed with methanol $(3 \mathrm{~mL})$ and water $(3 \mathrm{~mL})$. The flask was washed with $5 \mathrm{~mL}$ methanol-water $(10 \%, \mathrm{v} / \mathrm{v})$ which was then also transferred onto the cartridge. The cartridge was rinsed with $5 \mathrm{~mL}$ methanol $(10 \%, \mathrm{v} / \mathrm{v})$ and $5 \mathrm{~mL}$ water, dried under vacuum for at least $1 \mathrm{~min}$ and finally eluted with $6 \mathrm{~mL}$ methanol at a $1 \mathrm{~mL} / \mathrm{min}$ flow rate. The eluates were dried at $40^{\circ} \mathrm{C}$ under a stream of nitrogen and vacuum.

The residues were dissolved in $0.5 \mathrm{~mL}$ acetonitrile-water $(50 \%, \mathrm{v} / \mathrm{v})$. The supernatant was analyzed by ELISA and LC/MS/MS.

Recovery

Recoveries were calculated based on OD values of samples with different additional concentrations. OD values were interpolated from the standard curve using a computerized technique for automating calculation.

\section{RESULTS AND DISCUSSION}

Analysis of conjugate

Although the molecular masses of MPA-BSA and BSA are close, the conjugate band still tails that of BSA. Electrophoresis indicates that the two methods of coupling are both successful.

Scanning showed that the maximum wavelength of MPA is $247 \mathrm{~nm}$. The molar extinction coefficient of MPA $(\{\varepsilon\})$ was found to be 15015 by drawing a diagram.

\section{Calculation coupling rates of conjugate}

The absorbance of two different concentrations $\left(26\right.$ and $\left.65 \mu \mathrm{g} \mathrm{cm}^{-3}\right)$ of BSA and MPA-BSA at $\lambda=247 \mathrm{~nm}$ was determined and the calculated coupling rates were 14 and 13. 
The absorbance of two different concentrations of BSA and MPA-BSA at $\lambda=$ $247 \mathrm{~nm}$ was determined and the calculated coupling rates were 19 and 20.

Antibody titer

The highest titer of antiserum came to $2.6 \times 10^{5}$ according to Figure 1 .

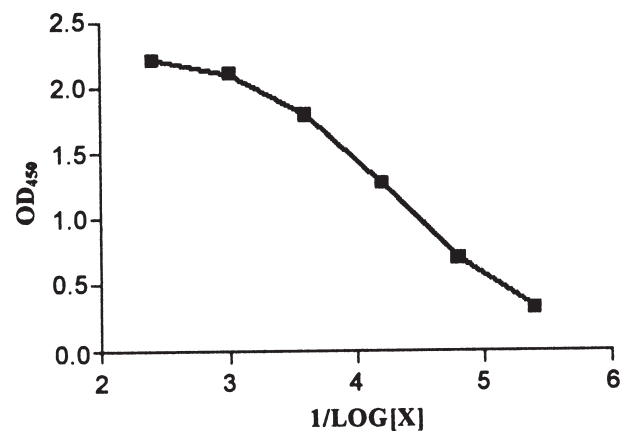

Figure 1. Determination of the titer of the antiserum by indirect ELISA

\section{ic-ELISA procedure}

The optimized ic-ELISA standard curve is shown in Figure 2. The maximum and minimum $\mathrm{OD}$ values were 1.05 and 0.16 , respectively, $\mathrm{IC}_{50}$ (concentration causing 50\% inhibition of binding) was $1.22 \mathrm{ng} / \mathrm{mL}$. LOD (the corresponding concentration causing $90 \%$ inhibition of binding) was $0.096 \mathrm{ng} / \mathrm{mL}$, assay range (the corresponding concentration of 20 80\% inhibition of binding) was $0.24 \sim 9.45$ $\mathrm{ng} / \mathrm{mL}$. The dashed lines of Figure 2 represent the concentrations causing of 90, $80,50,20 \%$ inhibition of binding, respectively.

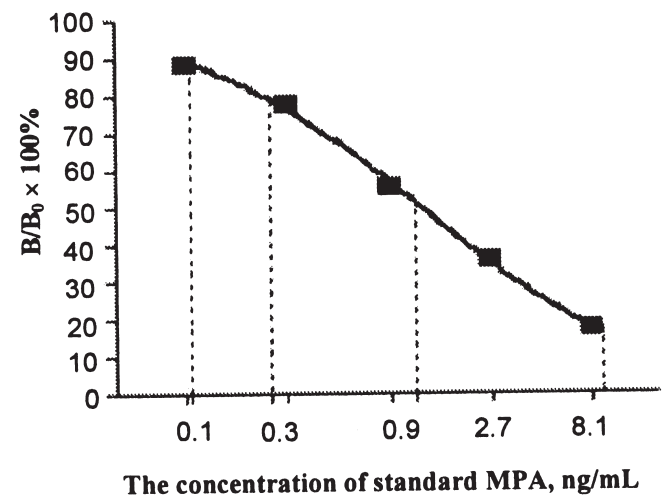

Figure 2. The calibration curve of ic-ELISA for MPA 
Cross reactivity (CR) assay

The cross reactivity of MPA antisera with anabolic steroid analogs was assessed by ic-ELISA. The CR of medroxyprogesterone is $96 \%$. CR of epitestosterone, nandrolone, $17 \alpha$-methyltestosterone and testosterone 17 -propionate is less than $0.1 \%$. The CR of $17 \beta$-oestradiol, oestriol, $17 \alpha$-ethynyloestradiol, oestrone, $17 \beta$ oestradiol 3-benzoate and progesterone (PG) is less than $20 \%$. The results are presented in Table 1.

TABLE 1

Cross reactivity of MPA antisera with anabolic steroids

\begin{tabular}{lc}
\hline Anabolic steroids analog & Cross reactivity, \% \\
\hline Medroxyprogoesterone & 96 \\
Oestradiol & 21 \\
17ß-oestradiol 3-benzoate & 16 \\
Progoesterone(PG) & 18 \\
Pregnenolone & 8 \\
Epitestosterone & $<0.1$ \\
Nandrolon & $<0.1$ \\
17 $\alpha$-methyltestostoerone & $<0.1$ \\
Testostoerone 17-propionate & $<0.1$ \\
Deoxycorticostoerone & $<0.1$ \\
17a-hydroxyprodestoerone & $<0.1$ \\
Prednisolone & $<0.1$ \\
Cortisol & $<0.1$ \\
Dexamethasone & $<0.1$ \\
\hline
\end{tabular}

\section{Precision and accuracy}

To assess the precision and accuracy of the assay, spiked MPA in muscle tissues at six concentrations corresponding to $0,0.1,0.3,0.9,2.7$ and $8.1 \mathrm{ng} / \mathrm{mL}$ was studied. As shown in Table 2, the coefficient of variation between microplates was 2.6 to $7.4 \%$. The coefficient of variation between batches was 5.7 to $9.5 \%$, that while in batches was 7.8 to $13.7 \%$ interassay. All of the coefficients of variation is less than $15 \%$.

TABLE 2

Coefficient of variation between microplates, batches and in batches $(n=6)$

\begin{tabular}{lccccccc}
\hline \multirow{2}{*}{ Item } & \multicolumn{7}{c}{ Standard concentration of MPA, ng/mL } \\
\cline { 2 - 8 } & blank & 0.0 & 0.1 & 0.3 & 0.9 & 2.7 & 8.1 \\
\hline \%C.V., between microplates & 7.4 & 4.7 & 5.6 & 5.8 & 2.6 & 3.8 & 2.9 \\
\%C.V., between batches & 9.5 & 6.9 & 8.2 & 7.9 & 6.5 & 5.7 & 6.1 \\
\%C.V., in batches & 13.2 & 13.7 & 11.5 & 12.1 & 7.8 & 8.5 & 10.3 \\
\hline
\end{tabular}




\section{Recovery}

Recovery of added MPA in the pork tissues was $72-91 \%$ for concentrations within the range of 1-3 $\mathrm{ng} / \mathrm{mL}$ of ELISA (Table 3).

TABLE 3

The average recoveries of samples were analysed by ic-ELISA

\begin{tabular}{lccccc}
\hline Sample & Number & $\begin{array}{c}\text { Added concentration of } \\
\text { MPA, ng/mL }\end{array}$ & $\begin{array}{c}\text { Average } \\
\text { value }\end{array}$ & $\begin{array}{c}\text { Coefficient of } \\
\text { variation, C.V.\% }\end{array}$ & $\begin{array}{c}\text { Rate of } \\
\text { recovery, \% }\end{array}$ \\
\hline Pork & \multirow{2}{*}{1} & 1 & 0.75 & 13.5 & 75 \\
tissue & 3 & 2.57 & 9.3 & 86 \\
& \multirow{2}{*}{2} & 1 & 0.72 & 12.4 & 72 \\
& \multirow{2}{*}{3} & 1 & 2.72 & 8.4 & 91 \\
& 3 & 0.81 & 12.1 & 81 \\
& 3 & 2.68 & 8.7 & 89 \\
\hline
\end{tabular}

To evaluate the performance of the LC-MS-MS method, blank pork samples were spiked at the level of 1.0 and $2.0 \mu \mathrm{g} / \mathrm{kg}$. Table 4 shows the results of fortification tests of each steroid in pork tissues. When spiked at the concentration of $1.0 \mu \mathrm{g} / \mathrm{kg}$, the average recovery of the MPA was $64 \%$ with a coefficient of variation $(\mathrm{CV})$ of $15 \%$. When $2.0 \mu \mathrm{g} / \mathrm{kg}$ were added, the average recovery of MPA was $76 \%$ and $\mathrm{CV}$ was $7.9 \%$.

TABLE 4

The recoveries and precision of LC/MS/MS method $(\mathrm{n}=6)$

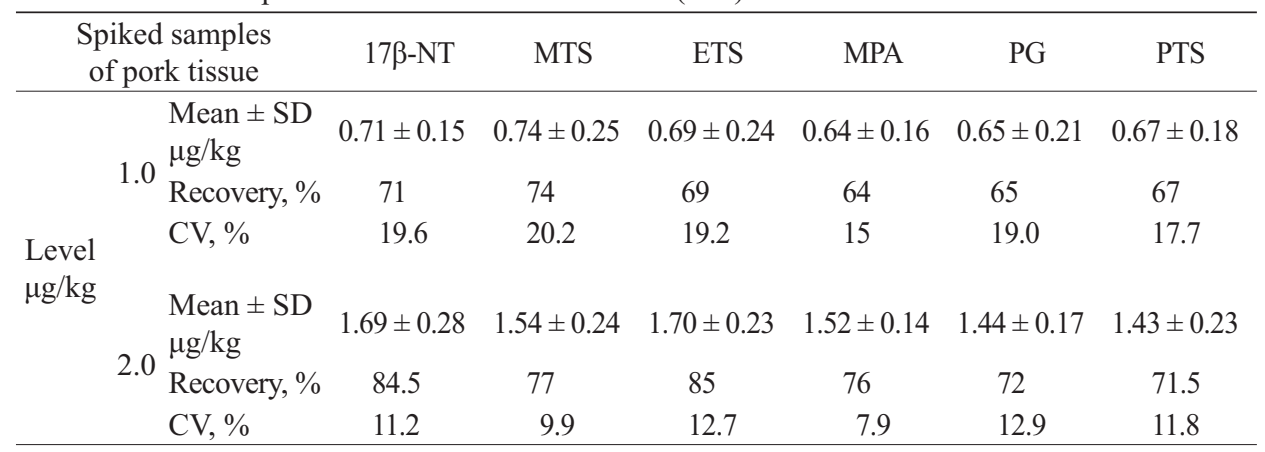

Comparison with LC/MS/MS

Six replicates for each concentration were determined by ELISA and HPLC/MS/MS. The result is shown in Table 5 and Figures 3-7. The ion pair for quantification of MPA was 345.2/123.1, the linear equation of MPA: $Y=6.68 \times 10^{3} \mathrm{X}+6.63 \times 10^{2}, \mathrm{r}=0.9998$. 
TABLE 5

Comparative results between ELISA and LC/MS/MS for MPA in pork tissues

\begin{tabular}{llllll}
\hline Method & \multicolumn{2}{c}{ ELISA } & & \multicolumn{2}{c}{ LC/MS/MS } \\
\cline { 1 - 2 } \cline { 5 - 6 } Added, $\mathrm{ng} / \mathrm{mL}$ & 1.0 & 2.0 & & 1.0 & 2.0 \\
Determined, ng/mL & 0.65 & 1.54 & & 0.64 & 1.52 \\
No. of determined samples & 6 & 6 & & 6 & 6 \\
\hline
\end{tabular}

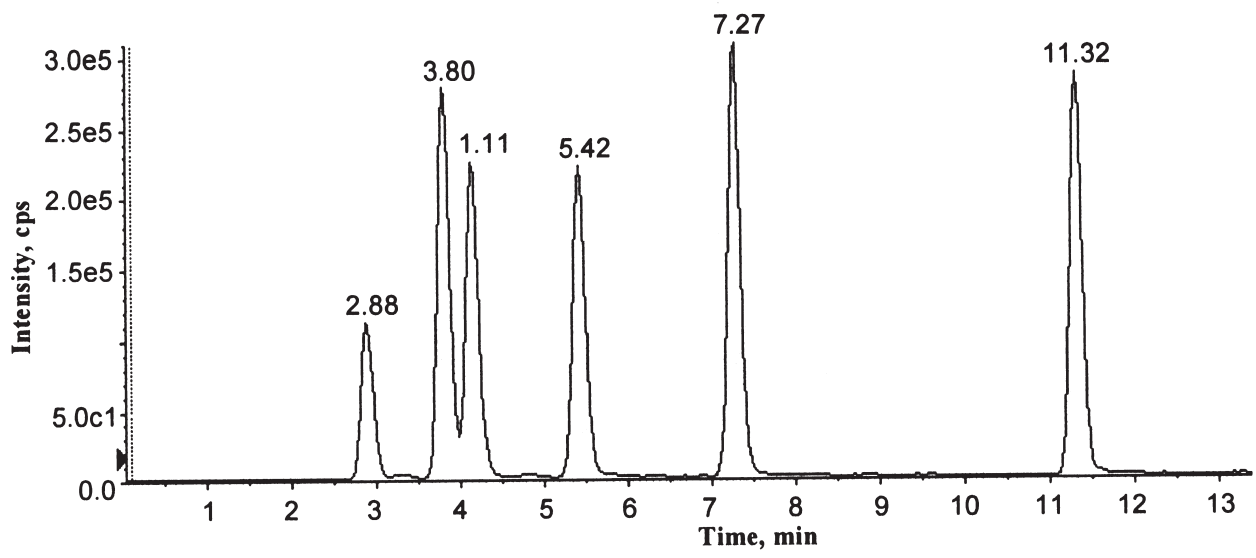

Figure 3. Total ion chromatography of standard androgens and progestogens in LC-MS-MS analysis. Conditions: TEM: $550^{\circ} \mathrm{C}$; IS: $3000 \mathrm{~V}$; CAD: 7.0 ; mobile phase: acetonitrile(A) and water(B), gradient used for elution: $0.01 \mathrm{~min}$ A $50 \%(\varphi), 15.0 \mathrm{~min}$ A $100 \%(\varphi) .10 \mu \mathrm{L}$ injection $\left(1 \mu \mathrm{g} \mathrm{ml} l^{-1}\right)$

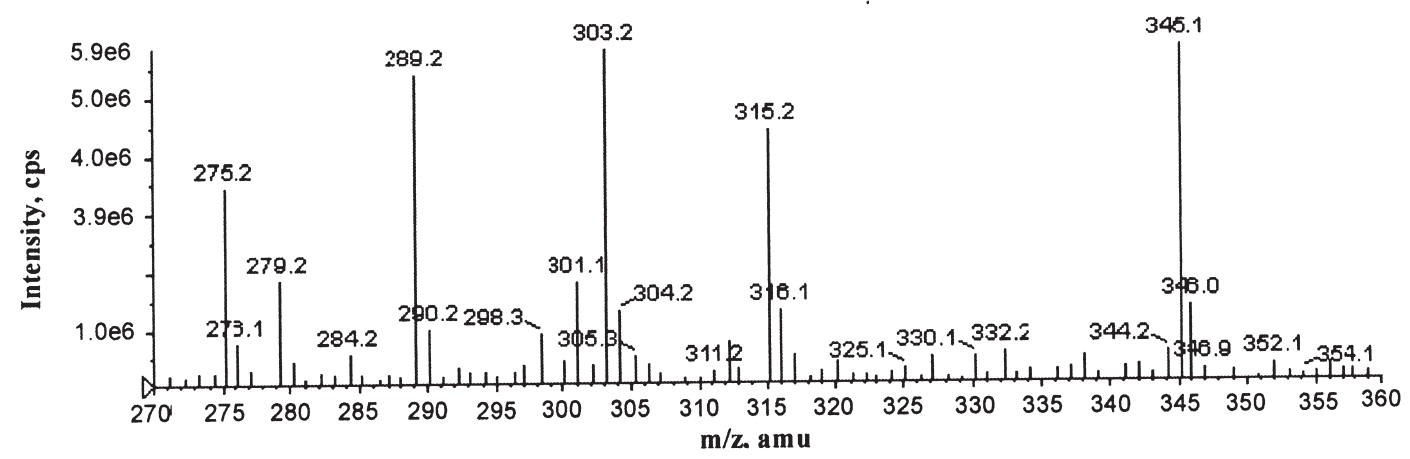

Figure 4. Full scan positive ESI Q1 scan of 17beta-NT, MTS, ETS, MPA, PG and PTS 


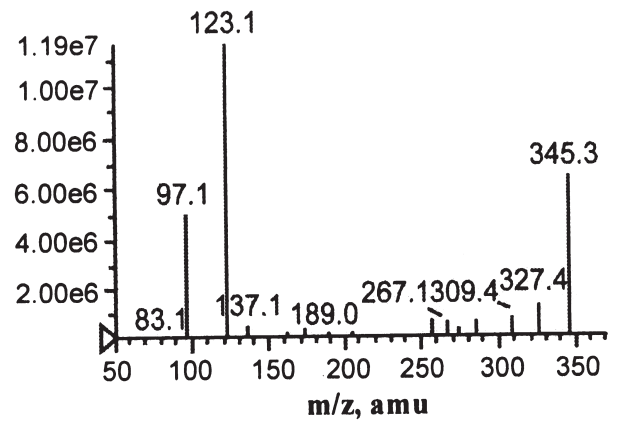

Figure 5. Full scan product ion spectra of MPA parent ion $\left[\mathrm{M}^{+} \mathrm{H}\right]^{+}$

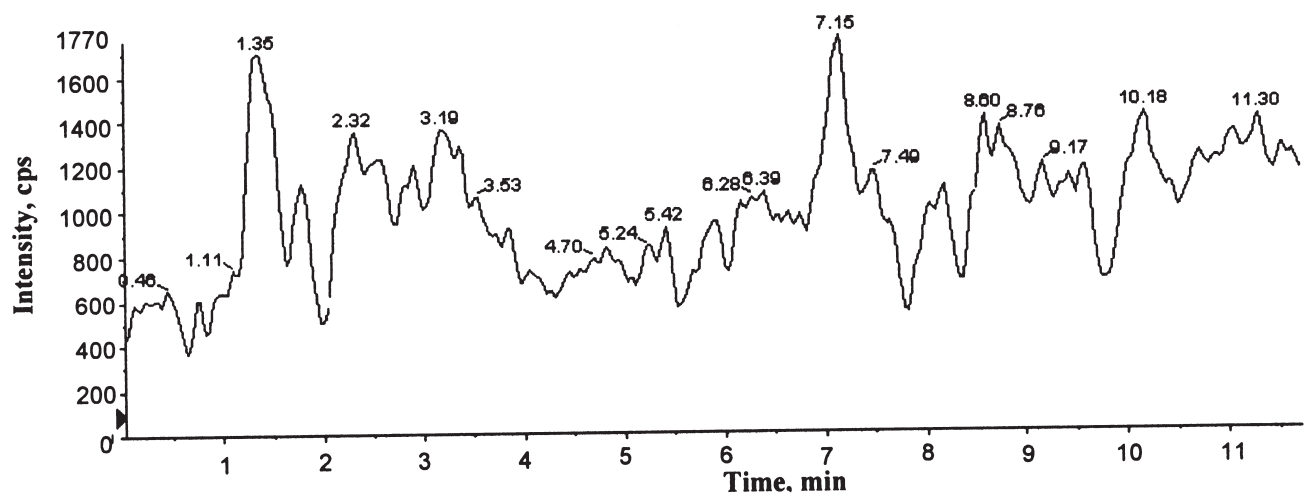

Figure 6. LC/MS/MS chromatography of androgens and progestins in blank pork tissues

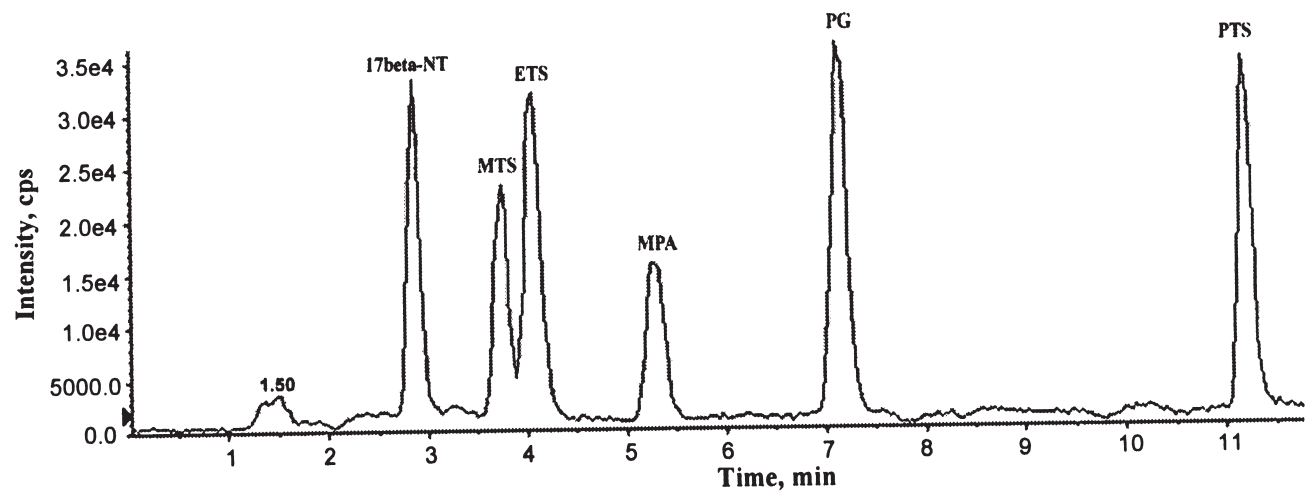

Figure 7. The LC/MS/MS chromatography of androgens and progestogens in spiked pork at $1.0 \mu \mathrm{g} / \mathrm{kg}$. Conditions: TEM: 550 ; IS: 3000V; CAD: 7.0; mobile phase: acetonitrile (A) and water (B), linear gradient used for elution: $0.01 \mathrm{~min}$ A 50\%, $15.0 \mathrm{~min}$ A $100 \% .10 \mu \mathrm{L}$ injection 


\section{$L O D$ and $L O Q$}

By determining the standard errors of blank samples, the limits of detection (LOD), defined as three times of the standard error of blanks, were obtained. Different matrixes did not affect the LOD of the analyte. The LOD of the method for MPA was $0.034 \mu \mathrm{g} / \mathrm{kg}$. The limits of quantification (LOQ) of the method were determined according to the formula $\mathrm{S} / \mathrm{N}=10$ and equalled $0.085 \mu \mathrm{g} / \mathrm{kg}$.

\section{CONCLUSIONS}

An ic-ELISA was developed and validated for the determination of MPA concentrations in animal muscle tissues. This assay is verified by HPLS/MS/MS. The two analytical methods can be applied to measure MPA at subnanogram levels, and are practicable for monitoring MPA and other anabolic steroid residues in foods.

\section{REFERENCES}

Bernard F.E., 1971. The preparation of antigenic hapten-carrier conjugate: A survey. Principles, Methods 70, 85-103

Choi M.H., Kim K.R., Chung B.C., 2000. Simultaneous determination of urinary androgen glucuronides by high temperature gas chromatography-mass spectrometry with selected ion monitoring. Steroids 65, 54-65

Daeseleire E., De Guesquiere A., Van Peteghem C., 1991. Derivatization and gas chromatographicmass spectrometric detection of anabolic steroid residues isolated from edible muscle tissues. J. Chromatogr. 562, 673-679

Draisci R., Palleschi L., Ferretti E., Marchiafava C., Lucentini L., Cammarata P., 1998. Quantification of $17 \beta$-estradiol residues in bovine serum by liquid chromarography-tandem mass spectrometry with atmospheric pressure chemical ionization. Analyst 123, 2605-2609

Lewis L.K., Elder P.A., Barrell G.K., 1992. An enzyme linked immunosorbent assay (ELISA) for plasma medroxyprogesterone acetate (MPA). J. Steroid Biochem. Mol. Biol. 42, 179-183

Marion M.B., 1976. A rapid and sensitive method for the quantities of protein utilizing the principle of protein dye binding. Anal. Biochem. 76, 248-254

Philippe A.G., Marie C.S., Richard H.S., 1999. Quantitative analysis of clenbuterol in meat products liquid chromatography-electrospray ionisation tandem mass spectrometry. J. Chromatogr. B 736, 209-219

Rambaud L., Bichon E., Cesbron N., André F., Bizec B.L., 2005. Study of 17 $\beta$-estradiol-3-benzoate, $17 \alpha$-methyltestosterone and medroxyprogesterone acetate fixation in bovine hair. Anal. Chim. Acta 532, 165-176

Rapp M., Meyer H.H., 1989. Determination of hormone contaminants in milk replacers by highperformance liquid chromatography and immunoassay. J. Chromatogr. 489, 181-189

Shen G.X., Zhou R.L., 1998, Techniques of Modern Immunological Experiment. Press of Scientific Technology in Hubei, Wuhan, pp. 157-158 
Stolker A.A., Zoontjes P.W., Schwillens P.L., Kootstra P.R., van Ginkel L.A., Stephany R.W., Brinkman U.A., 2002. Determination of acetyl gestagenic steroids in kidney fat by automated supercritical fluid extraction and liquid chromatography ion-trap mass spectrometry. Analyst 127, 748-754

Wang C.Q., 1997. Basis of Molecular Immunology. Press of Beijing University, Beijing, pp. 13-15 Wang J.Z., Fan M., 2000. Handbook of Protein Technology. Press of Science, Beijing, pp. 111-122 Yang L.G., Hu S.C., Wei P.H., Guo A.Z., 1998. Techniques of Enzyme Immunoassay. Press of Nanjing University, Nanjing, pp. 189-284

Zhou X.W., Hu X.Q., 2003. Instrumental Analysis and Experimental Technology of Biochemistry. Press of Chemistry Industry, Beijing, pp. 271-272

Yu N.H., Ho E.N.M., Leung D.K.K., Wan T.S.M., 2005. Screening of anabolic steroids in horse urine by liquid chromatography-tandem mass spectrometry. J. Pharmaceut. Biomed. Anal. 37, 1031-1038

\section{STRESZCZENIE}

Wykrywanie pozostałości octanu medroksyprogesteronu w tkance mięsnej zwierząt stosując procedurę sprzężenia enzym-immounosorbent oraz tandem chromatografii cieczowej i spektrometrii masowej

Octan medroksyprogesteronu (MPA), o względnej masie cząsteczkowej 344,5 nie wykazuje aktywności immunologicznej. Do połączenia MPA z bydlęcą albuminą (białkiem nośnikowym) wykorzystano dwie metody, karbodimidową i mieszaną bezwodnikowa, a tempo sprzęgania konjugatów oszacowane przy użyciu spektrometru UV wynosiło odpowiednio 14 i 20. Analiza SDS-PAGE potwierdziła prawidłowość wiązania. Króliki białe-nowozelandzkie były immunizowane cząsteczką, której wartość łączenia wynosiła 14, a krew została pobrana po 5 okresach immunizacji. Miano antysurowicy oznaczane pośrednio metodą ELISA wynosiło $2,6 \times 105$. Oczyszczone przeciwciała zostały użyte do oszacowania kompetencyjnej metody ELISA. Metoda ta zapewniała limit detekcji MPA równy 0,096 ng/mL, odzyski (z tkanek jadalnych) mieściły się w granicach od 72 do $91 \%$, a roboczy zakres od 0,1 do 8,1 ng/Ml. Wstępna ocena przydatności testu obejmowała jej specyficzność, czułość, precyzję oraz dokładność i wykazała, że może być ona stosowana do detekcji MPA w tkankach. Ponadto, została ona porównana z metodą wysokosprawnej chromatografii cieczowej i spektrometrii masowej. Do ilościowej detekcji MPA wykorzystywano następującą parę jonów: 345,2/123,1, natomiast liniowe równanie kalibrujące zawartość MPA miało następującą postać: $\mathrm{Y}=6,68 \times 103 \mathrm{X}+6,63 \times 102$. Te dwie metody analityczne mogą być stosowane do monitorowania MPA i innych anabolicznych steroidów w artykułach spożywczych pochodzenia zwierzęcego. 